Cómo citar este trabajo: Almirón Mengibar, M. A. (2020). Feminismos y sexualidad: Placer y peligro, versus libertad y censura. De los debates feministas (inacabados) de fin de siglo, a los de hoy. Revista del Laboratorio Iberoamericano para el Estudio Sociohistórico de las Sexualidades, 04 art. 14, 371-396. https://doi.org/10.46661/ relies.5112

\title{
Feminismos y sexualidad: Placer y peligro, versus libertad y censura. De los debates feministas (inacabados) de fin de siglo, a los de hoy
}

\author{
Feminisms and sexuality: Pleasure and danger / freedom and censorship. \\ From the (ongoing) feminist debates of the end of the century to those of \\ today
}

\author{
Ana Almirón Mengibar \\ Feminista y Activista pro Derechos Humanos. \\ almironmariaantonia@gmail.com
}

Resumen

El 11/09/2019 la Universidade da Coruña (UDC) suspende una jornada de debate sobre trabajo sexual al no poder garantizar su seguridad, dado el "fuerte rechazo, acoso y crueldad" recibidos, tras la polémica protagonizada por activistas abolicionistas bajo el hashtag \#UniversidadSinProstitución, denunciando la iniciativa y afirmando que formaba parte de la estrategia del "lobby proxeneta". Apenas un mes después, el 18/10/2019, 22 universidades de todo el estado hacen público un programa colectivo tratando de abrir un debate en libertad sobre trabajo sexual, bajo el hashtag \#UniversidadSinCensura, que pudiera arrojar luz sobre ello, dando voz además, como algo fundamental, a las propias protagonistas. Debate en el que se inscribe este Monográfico. Un debate por tanto no solo académico, sino social y político, pero ni novedoso ni con un único punto de vista feminista al respecto, a lo largo de los casi cincuenta años de debates feministas de este país, desde sus inicios como movimiento social (años 70) hasta la actualidad, transitando entre el placer y el peligro hacia el reconocimiento de la diversidad y libertad sexual, contra la estigmatización, censura y prohibición de derechos. Debates feministas que hemos querido trasladar aquí, de forma obligatoriamente resumida, mostrando la pluralidad de ideas y 
propuestas, desde entonces hasta hoy, planteándonos finalmente cuales podrían ser los retos actuales del movimiento feminista, en un contexto de creciente conservadurismo estatal y global.

Palabras clave: Feminismos, Sexualidad, Institucionalización, Movimientos Sociales.

Abstract

On 11/09/2019, the University of A Coruña (UDC) cancelled a debate on sex work, thus giving in to the attitudes of "strong rejection, harassment and cruelty" it had triggered. Abolitionist activists had denounced the initiative, under the hashtag \#UniversitywithoutProstitution (\#UniversidadSinProstitución), as part of a strategy led by the "pimp lobby". About one month later, on 18/10/2019, 22 Spanish universities announced a series of academic events that, under the hashtag \#UniversityWithoutCensorship (\#UniversidadSinCensura), aimed to open a free debate on sex work nationwide, one that would shed light on it and, crucially, give voice to the protagonists themselves. This monographic issue is part of that debate. Debates on sex work are not only academic, but also social and political. Nor are they novel, or based on a single feminist standpoint. They have been part of the Spanish feminist movement during almost fifty years, from its beginnings in the 1970 s to the present day. There they have tried to overcome the dichotomy pleasure/danger and recognise diversity and sexual freedom, rejecting stigmatization, censorship and the prohibition of rights. This article aims to offer a brief review of these debates, thus showing their openness and the plurality of ideas and proposals presented in them until today. It also reflects on the current challenges faced by the feminist movement in a context of increasing national and global conservatism.

Key words: Feminisms, Sexuality, Institutionalization, Social Movements. 


\section{Introducción}

Este artículo no pretende hacer una revisión exhaustiva y objetiva del movimiento feminista en el estado español, su organización, acciones, reivindicaciones y luchas, ni de sus logros o fracasos, si no que centra su interés en algunos de los principales debates relacionados con la sexualidad, percibida, con diferentes acentos, como placer y peligro a la vez. Debates feministas que han suscitado cuestiones de mucho interés y que no se han cerrado ni mucho menos a lo largo de todos estos años, como bien ha puesto de relieve el debate actual sobre trabajo sexual, sin que haya, pensamos, suficiente conciencia o conocimiento de ello. De ahí que queramos traerlos a colación aquí.

Tras la revisión bibliográfica disponible, pensamos que faltaría una visión más desde las propias protagonistas del movimiento feminista, cuya producción de ideas surgidas del debate interno y de la propia dinámica de acción social y política, han quedado reflejadas en un conjunto de materiales, actas de las múltiples jornadas celebradas y todo tipo de documentación, cuyos planteamientos y enfoques no han tenido suficiente repercusión en el ámbito académico, de una parte, por desconsideración o falta de los recursos institucionales necesarios que facilitaran su acceso y difusión, y por otra, porque los estudios e investigaciones llevadas a cabo han quedado excesivamente encerrados en el ámbito académico de "estudios de la mujer", impregnando solo parcial e insuficientemente el discurso académico general y la crítica feminista al pensamiento de nuestra época. El caso es que, en demasiadas ocasiones, nos acercamos a los debates actuales como si los problemas y posicionamientos que subyacen no se hubiesen planteado ni debatido con anterioridad o, peor aún, como si solo hubiese un único punto de vista feminista previo al respecto, institucionalizado como el políticamente correcto. Estos elementos hacen que nos parezca de interés hacer esta revisión desde la perspectiva de las propias protagonistas, a partir de la cual profundizar en la diversidad de puntos de vista en cada uno de esos debates, fruto de un movimiento feminista plural desde sus inicios hasta hoy, reforzando la idea de que cuando hablamos de Movimiento Feminista siempre estamos hablando de feminismos en plural y no de un solo, único y excluyente, pensamiento feminista.

Hemos resumido esos debates feministas de final de siglo en las siguientes etapas:

En un primer lugar, nos referiremos a los debates que se dieron en sus orígenes, en los años 70: las "I Jornadas de la Liberación de la Mujer" del 75 en Madrid; las "I JJ Catalanas de la Dona" del 76 en Barcelona; y las "II JJ Feministas Estatales" del 79 en Granada. Se trata de debates relacionados con el cambio democrático y la Constitución del 78 y que versaron sobre adulterio, divorcio, anticonceptivos y aborto. En ellos ya se puede percibir la aparición de las distintas corrientes de pensamiento feminista, los feminismos.

En segundo lugar, abordaremos los debates de los 80: las JJ. del Aborto del 81 y las de Sexualidad del 83 en Madrid ("sexualidad no es maternidad", pornografía y prostitución); las "JJ. Diez años de lucha del movimiento feminista" de Barcelona del 85; las de Lesbianismo del 87; y las JJ. del 88 "Contra la violencia machista" de Santiago; todas muy concurridas, pese a la institucionalización del feminismo (el IME se crea en el 83) y las diferencias de opinión en cada uno de esos temas de las distintas corrientes feministas. Pese a todo, a dichas jornadas asistía todo el mundo feminista y el movimiento seguía teniendo un fuerte componente unitario de lucha. 
- $\quad$ En tercer lugar, nos centraremos en los años 90, cuando el movimiento acusaba cansancio y el caso de Alcacer en el 92, muy mediatizado, generó un grave estado de alarma social sobre la violencia sexual. No obstante, se organizaron las JJ. Estatales del 93 "Juntas y a por todas" en Madrid, muy numerosas, con participación por primera vez de investigadoras académicas y dos importantes mesas de debate, una sobre Transexualidad y otra sobre Prostitución. En 1995 se crea Hetaira en Madrid. Y en el 2000 se celebraron las JJ. Estatales "Feminismo es y será" en Córdoba.

Este resumen no incide en los ejes temáticos ni mesas de debate de las múltiples Jornadas (dos monográficas y 5 generales). Somos conscientes por ello de que no muestra la amplitud de temas abordados. Sin embargo, el objetivo de este artículo es seleccionar, dentro de esos debates, aquellos más directamente relacionados con la sexualidad. De ahí que, tras explicitar la metodología que vamos a seguir, dedicaremos un breve apartado a los antecedentes históricos previos a la aparición del movimiento feminista, su punto de partida, tratando de recoger las polémicas suscitadas por algunas mujeres ilustradas y pro sufragio durante la II República, la Guerra Civil y la Dictadura. En otro apartado quisiéramos mostrar, a grandes trazos, los planteamientos al respecto de las distintas corrientes de pensamiento feminista, los feminismos, la pluralidad de este movimiento. Abriremos un tercer apartado en el que abordaremos la creciente diversidad, las distintas formas de ser mujer/hombre desde donde reivindicar una perspectiva feminista crítica y, finalmente, un apartado dedicado más directamente a la sexualidad, percibida como placer y peligro a la vez: sexualidad no es maternidad, pornografía, prostitución, violencia machista y otras cuestiones relacionadas.

Debates feministas de finales de siglo, decíamos, que han suscitado cuestiones de mucho interés, que ni mucho menos se han cerrado a lo largo de todos estos años, sino que continúan debatiéndose, hasta hoy. Así, tras las JJ. de Córdoba del 2000 "Feminismo es y será", en 2009 se celebraron unas nuevas JJ. Feministas Estatales en Granada, treinta años después de las del 79, sobre las que J. Iturrioz, en "Feminidad hegemónica y perversidad" (2020) decía lo siguiente:

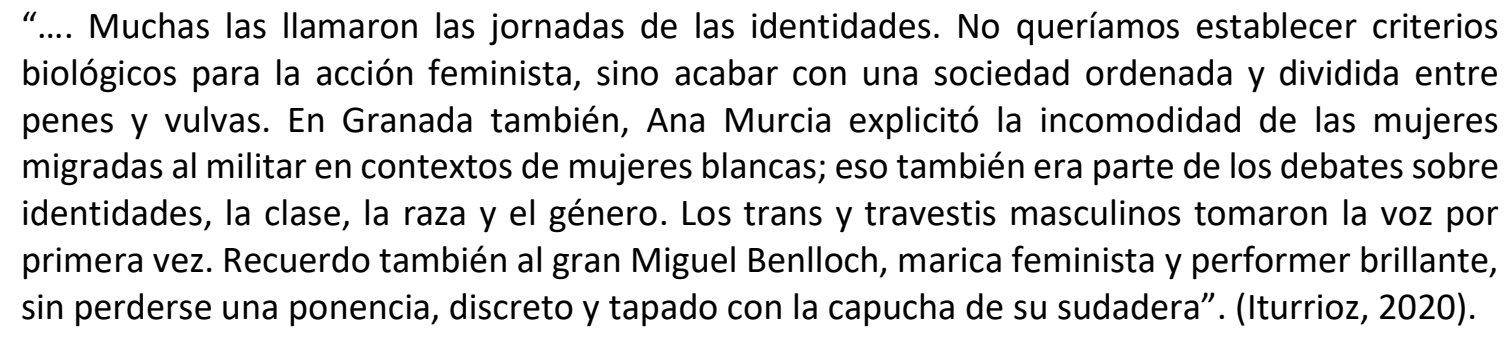

Y tras las JJ. de Granada de 2009, cuarenta años después de las del 79, el 11/11/2019, se suspende la Jornada sobre Trabajo Sexual en la Universidad da Coruña y el 18/10/2019 22 universidades organizaban jornadas para debatir en libertad sobre trabajo sexual. Jornadas que trataron de impedir por todos los medios, prohibiéndolas o violentando directamente con escraches e insultos de "proxenetas" a quienes las organizaban, traspasando así todas las "líneas rojas" respetadas hasta entonces en los debates de las disidencias feministas. Tal vez lleve razón J. Iturrioz en el artículo citado cuando dice:

“Hace doce años, pensábamos que ser mujer no era nada, tan solo un devenir impuesto, una posición subordinada. Ahora parece que ser mujer lo es todo. La bronca está dentro. Antes el poder era la capacidad de hacer cosas, ahora el poder es el poder". (Iturrioz, 2020).

Por eso, finalmente, intentaremos sacar conclusiones de esos debates feministas y su relación con los de hoy, planteándonos cuáles serían los retos actuales del movimiento feminista, que girarían, pensamos, en torno al reconocimiento de su pluralidad, diversidad y autonomía respecto a las instituciones y los partidos, en un contexto político de creciente conservadurismo autoritario. 
Para acercarnos a nuestro objetivo, un análisis de algunos de los debates del movimiento feminista desde su aparición en los 70, partimos de la experiencia vivida. Una mirada y perspectiva por lo tanto diferente a las más usuales, que aporta desde dentro, por quien ha sido parte activa de la realidad analizada sin el filtro de otros mediadores, en la que se asume la reflexividad como elemento consustancial a cualquier acercamiento a una realidad social de la que ineludiblemente formamos parte (Giddens, 1997). Se opta por lo tanto por una perspectiva autobiográfica, en parte ya publicada (Almirón, 2019), a la que se ha recurrido a modo de "diario de campo" y que construye una narrativa nutrida a partir de la memoria y la remembranza de experiencias vividas, pero también de la consulta y estudio de fuentes primarias procedentes del archivo propio y personal acumulado a lo largo de todos estos años. Se entrelazan las referencias bibliográficas, los materiales originales utilizados y creados desde el propio movimiento feminista a lo largo de su historia, con la propia experiencia vivida, lo que nos sitúa en el ámbito de la auto-etnografía como elemento narrativo generador de conocimiento, en la que la implicación en el movimiento feminista de quien firma rompe la dicotomía investigadora/investigado, conectando, como dice Ellis y Bochner, "lo personal con lo cultural" (citado en Blanco, 2012: 172). Esta opción metodológica ha requerido también un importante esfuerzo de "extrañamiento" que permita objetivar y combinar una doble mirada, "emic" y "etic", que irán apareciendo en los diferentes puntos del artículo.

\section{Debates de fin de siglo del movimiento feminista en el estado español}

El movimiento feminista surgido en el ámbito anglosajón y norteamericano a finales de los 60/70 nació ligado a la Nueva Izquierda que se oponía al sistema capitalista, a la Guerra de Vietnam o a la segregación racial en EEUU:

“(...) pronto empezaron a cuestionar rasgos fundamentales de la modernidad capitalista que la socialdemocracia había naturalizado hasta entonces: el materialismo, el consumismo, y $<<l a$ ética del triunfo >> la burocracia, la cultura corporativa y el $<<$ control social >; la represión sexual, el sexismo y la heteronormatividad". (Fraser, 2013:80).

Aunque el movimiento feminista organizado de los años 70 en España surge igualmente en un contexto de cambio político democrático y apertura sociocultural que guarda similitudes con los feminismos de otros países europeos y americanos, también tiene importantes diferencias y particularidades, como señala Gahete (2018):

“... frente a la limitada repercusión de la primera ola del movimiento feminista en España, durante los años setenta y ochenta el feminismo penetró en España con gran fuerza. Las corrientes feministas vieron favorecida su entrada por la propia situación social y política que se estaba viviendo. Los cambios sociales que ya desde la década de los sesenta estaban teniendo lugar, y que afectaron de forma significativa a las mujeres con una mayor incorporación de éstas al trabajo asalariado, a la universidad y su cada vez mayor participación política, especialmente, en los barrios y universidades, ayudaron a que las mujeres fuesen progresivamente concienciándose no solo de la falta de libertades que la sociedad española tenía, sino de su propia falta de libertad como individuo y que venía dada por el hecho de nacer mujer" (Gahete, 2018: 253).

Efectivamente, en España, alrededor del año 75, al comienzo de la transición democrática, emergería un feminismo progresista y transgresor, sumando la lucha feminista a la de los llamados nuevos movimientos sociales, con su crítica anticapitalista, ecologista, antirracista y antimilitarista. Quien suscribe este artículo, formando parte de este movimiento desde los años 70 en Barcelona, hasta hoy en Sevilla, describía así, la situación política, las protagonistas y el ambiente sociocultural que se respiraba: 
"Soy ante todo una mujer feminista de los años 70, del llamado feminismo de la "tercera ola", que además de reivindicar derechos civiles y políticos (educación, sufragio), hemos reivindicado derechos sociales (control de natalidad, anticonceptivos, aborto, divorcio). La igualdad real y no meramente formal, rechazando los privilegios masculinos, repudiando la violencia machista, rompiendo los estereotipos de género a favor de la diversidad de opciones sexuales y de género, reconociendo las diferencias que nos marcan la clase y la etnia, reivindicando nuestra sexualidad y la libertad sexual, lo que en la práctica me ha situado como una mujer que ha cabalgado entre ese feminismo de la "tercera ola" y lo que ahora se denomina feminismo de la "cuarta". La diversidad por lo tanto es un elemento que marca mi forma de vivir y percibir eso de "ser feminista...... Soy además de izquierdas, podríamos decir que de una "tercera ola" igualmente, que surge en la década de los 60 , una izquierda que, aun siendo parte, se distancia de las incipientes corrientes del SXVIII y de las marxistas del SXIX y XX, orientando mi actuación más al ámbito de lo social que al estrictamente político,....Soy y me siento migrante, mi origen andaluz, mi migración a Catalunya donde se desarrolla mi formación en tantos sentidos y mí vuelta posterior a Andalucía, conforman una particular identidad cultural, fruto de cruces, aprendizajes y, nunca mejor dicho, mestizajes .."

"Dudé entre irme a estudiar a Francia o hacer Económicas en Barcelona, donde finalmente me matriculé, huyendo claramente de la típica carrera femenina. Así que de día trabajaba y por la tarde tenía las clases en CC.EE, donde las mujeres éramos más que escasas... Mi primer curso fue el $72 / 73$ y en plena lucha antifranquista, la Universidad era un ir y venir de asambleas, comités de solidaridad, luchas, paros y huelgas, ... Allí conocí a los primeros grupos de estudiantes anarquistas con los que más me relacionaba, a los primeros trotskistas partidarios de la Revolución Permanente y de la Revolución Sexual de W. Reich, que ya recibía críticas de algunas de nosotras porque aquella revolución les venía que ni pintada a los hombres"

“... trabajando, siendo Enlace Sindical y activista estudiantil antifranquista, no aprobé aquel primer curso, pero me volví a matricular de nuevo en el curso $73 / 74$, años cada vez de mayor agitación dado el inminente final de la dictadura... No eran meses de estudio y el poco tiempo que restaba lo pasaba en Barcelona, debatiendo, paseando y descubriendo los entresijos de la ciudad. Rambla arriba y abajo conocí a Ocaña, travestido y provocador, reivindicando con su arte sus orígenes andaluces y su homosexualidad. Paseaban también otras pandillas de jóvenes visibilizando ya a quienes germinarían poco más tarde en el Front d'Alliberament Gay de Catalunya (FAGC). Me acerqué a algunos locales donde Bibí Anderson aireaba igualmente su transexualidad hasta llegar a ser la Bibiana Fernández actual. La Rambla era una mezcla de gentes llegadas de todos sitios, como aquellos negros que tocaban el saxo a ritmo de blues. Al final de la Rambla a la derecha el puterío del Distrito № al que conseguirían echar a lugares menos seguros para ellas. Y a la izquierda, los bares de la Plaza Real donde tomar unas cervezas y cientos de tabernas y locales donde escuchar la buena música de Pau Riba o Jaume Sisa, ... Y que os voy a contar del Paralelo, de Gracia o de Sants, del Cine Princesa o de Santa María del Mar... Os puedo contar que aprendí, vi, oí y reconocí la grandeza y la belleza de una ciudad tan diversa, plural y mestiza, a la cabeza de muchos de los cambios y sueños de libertad que se avecinaban" (Almirón, 2020: 353/382).

Podemos observar por tanto coincidencias en el momento de su aparición, entre el movimiento feminista español y el anglosajón, en concreto entre el contexto internacional de apertura de los 60 y el particular momento de cambio político aquí, más tardío, a mitad de los 70 , tras cuarenta años de dictadura. Nos parece imprescindible constatar también las importantes diferencias existentes en los antecedentes históricos previos, que marcarán las dificultades del movimiento feminista de los 70, en una sociedad española particularmente machista y conservadora, señalando a grandes trazos el particular camino recorrido, los avances y retrocesos en la consecución de los derechos de las mujeres, contrastándolo en alguna medida con el de otros países del entorno europeo y EEUU. 


\title{
3 Antecedentes históricos
}

\subsection{De ilustradas a sufragistas}

Aunque de forma tardía se constituyeron en España algunas asociaciones de mujeres por el derecho al voto, no hubo aquí un movimiento sufragista semejante al de EEUU ni Gran Bretaña. Geraldine Scanlon, (Scanlon,1990) relaciona ese tardío desarrollo del feminismo español en el siglo XX, con el lento crecimiento de las clases medias, la no consolidación de una tradición de liberalismo político y un sistema sólido de democracia parlamentaria, así como al peso conservador de la iglesia católica a lo largo de su historia. Y según Soraya Gahete:

\begin{abstract}
“España se ha caracterizado por ser un país donde el peso conservador de la Iglesia católica ha marcado a lo largo de la historia las pautas sociales e incluso las políticas, estableciendo también modelos femeninos adecuados e inadecuados... En el siglo XIX surgió en el mundo occidental un nuevo modelo femenino denominado <ángel del hogar>, rescatado posteriormente por la dictadura franquista...En los años veinte del siglo XX, apareció un nuevo modelo femenino... La garçonne en Francia y la flapper en Inglaterra encarnan un nuevo ideal femenino de individualidad, libertad e igualdad...mujeres que aspiraban a adquirir una cultura y cierta autonomía personal, a la vez que luchaban por conseguir los derechos propios del ser humano, fueron duramente criticadas por la sociedad de su tiempo, hasta establecer que eran un tercer sexo, una especie de invertido moral y antinatural. ... Este nuevo modelo femenino conocido también como la "Mujer Nueva" o "Mujer Moderna" tuvo que enfrentarse al discurso médico, además del religioso, sobre la maternidad". (Gahete, 2018: 107-108).
\end{abstract}

En los años 20 hubo también en España mayor participación pública de las mujeres, creándose la Asociación Nacional de Mujeres y la Unión de Mujeres Españolas en 1918, en 1919 el Consejo Supremo Feminista de España, órgano coordinador desde el que se articuló la lucha por el voto femenino y en 1920 la Asociación Universitaria Femenina. Durante la Dictadura de Primo de Rivera (1923-1930) hubo reformas que mejoraron la situación de las mujeres, pudiendo votar y ser elegidas concejalas y alcaldesas, en Diputaciones y Asamblea Nacional ("varones y hembras, solteras, viudas o casadas autorizadas debidamente por sus maridos"), interviniendo por primera vez en el Congreso una mujer, Concepción Loring y Heredia (Gahete, 2018: 111). Y en los años 20 las mujeres empezaron la abogacía, destacando Clara Campoamor, Matilde Huici, Victoria Kent o Concepción Peña Pastor, intentando derogar artículos del Código Civil (obediencia de la esposa al marido) y Penal (condenaba al hombre que mataba a su esposa o al compañero de ésta solo a una pena de destierro si demostraba que había cometido adulterio - "uxoricidio por causa de honor"-).

\subsection{La II República}

La proclamación de la II República el 14 de abril de 1931 abre un periodo de importantes reformas y cambios sociales que venían gestándose desde los años 20 (reducción de la tasa de analfabetismo femenino del $70 \%$ al $48 \%$, mayor incorporación a la educación superior y a las nuevas profesiones de telefonista o mecanógrafa, disminución de la natalidad, etc.) y los derechos de las mujeres empiezan a igualarse a los de los hombres, apareciendo mujeres que rompen con el modelo del ángel del hogar, replanteando su situación en el matrimonio. La politización de las mujeres se incrementa, en parte debido a la consecución del voto y su uso electoral por parte de los partidos, naciendo nuevas asociaciones, como la Unión Republicana Femenina de Clara Campoamor en1931 para la obtención del sufragio femenino, o la Asociación Femenina de Educación Cívica de María Lejárraga en 1932. Y se producen sobre todo cambios jurídicos bastante avanzados, aunque las mentalidades estuviesen poco evolucionadas aún, como la interdicción de discriminación por razón del sexo gracias a Clara Campoamor; la apertura a las mujeres de cargos públicos; su protección en el trabajo, con la regulación del seguro de enfermedad, accidente, paro y maternidad; la igualdad en el matrimonio y su posible disolución de mutuo acuerdo, así como la igualdad entre hijos

Revista del Laboratorio Iberoamericano para el Estudio Sociohistórico de las Sexualidades https://doi.org/10.46661/relies.5112 
legítimos e ilegítimos; o como el sufragio igualitario para ambos sexos, aunque de 470 diputados en las Cortes Constituyentes, sólo dos eran mujeres, Victoria Kent del Partido Radical Socialista y Clara Campoamor del Partido Radical, incorporándose más tarde Margarita Nelken, del Partido Socialista.

El periodo más reformador fue el primer bienio, entre 1931 y 1933 . Así, y a modo de ejemplo, en 1931 se concedió a las mujeres el derecho a ser miembros de jurados, si bien sólo en el caso de los llamados "crímenes pasionales" (aquí los jurados habrían de tener el mismo número de mujeres que de varones), excluyéndoselas de jurados donde se tratasen delitos como aborto, infanticidio o violación, al considerarse que podían ser parciales. De 1932 es la Ley de Matrimonio Civil y supresión de los delitos de adulterio en la mujer y amancebamiento en el hombre; en 1933 se derogó la pérdida de la patria potestad de las viudas y divorciadas sobre sus hijos/as, aunque sin una reforma del Código Civil quedara sin carácter legal que las mujeres extranjeras pudieran mantener su nacionalidad de origen distinta a la del marido; y se logró equiparar la mayoría de edad en ambos sexos a los 23 años. Desde 1933, con la llegada al poder de un gobierno de derechas, y sobre todo a partir del 34, el clima de violencia, con el ascenso del nazismo en Alemania y la radicalización del régimen fascista italiano, llevará a manifestaciones y huelgas, con una importante presencia femenina. En 1935 se pusieron en marcha medidas para abolir la prostitución, tras una intensa campaña del Patronato de Protección de la Mujer, y el aborto sólo fue legalizado a finales del 36 en Cataluña. Poco sabemos del alcance real de todas estas reformas en las relaciones de género. La corta duración de la República y de su primer gobierno más reformador, así como los conflictos que tuvo que enfrentar, hacen difícil un balance claro. Jurídicamente hubo pues claros avances, pero el modelo de familia seguía siendo el tradicional, cuyo peso recaía en el varón que seguía siendo representante legal de su esposa, y cuya autorización necesitaba la mujer para poder firmar un contrato laboral.

\subsection{La Guerra Civil}

La guerra civil tras el Golpe de Estado del 18 de julio del 36, con un marcado componente de género, afectó profundamente a las españolas, ya que en ella se jugaba, entre otras cosas, lo que la República había significado para las mujeres. Por ello, la implicación política de las mujeres en ambos bandos fue muy importante. Unas estaban dispuestas a morir "por la Patria", al representar mejor que nadie la abnegación y el sacrificio femenino que toda mujer debía tener. Otras, fieles a la República, identificaban la igualdad de los sexos con el triunfo republicano, advirtiendo de la esclavitud de las mujeres en los regímenes fascistas, cuya única misión era la reproducción, produciéndose una fuerte división de la población femenina, entre buenas y malas. (Gahete, 2018). La imagen de la mujer fue utilizada por ambos bandos, en algunos casos con consignas muy similares, para conseguir la movilización femenina y su apoyo social. La mujer republicana será también representada como madre y esposa, junto a la imagen de la miliciana llamando a participar en el frente. Aunque el hecho más significativo fue la participación de un grupo reducido de mujeres en la acción militar de la zona republicana, esto duró poco, ya que en el intento de crear un ejército regular acabando con las columnas milicianas, el ministro de Guerra, Largo Caballero, promulgó un decreto en octubre del 36 que prohibía a las mujeres ir al frente, estando su misión en la retaguardia. $Y$ es en la retaguarda donde las encontramos a unas y otras, en labores de enfermería, propaganda, costura, etc., asumiendo además tareas y responsabilidades que anteriormente les habían estado vedadas o restringidas, en la industria de guerra o puestos de trabajo cualificados abandonados por los hombres al irse al frente, encontrándonos mujeres conductoras de tranvías o camiones, altos puestos en la administración, etc. Una de las actividades más importantes llevadas a cabo por mujeres, en ambas zonas, fue en organizaciones destinadas a poner a salvo a las niñas y niños, así como labores para poner a buen recaudo el patrimonio cultural o denunciar las acciones de represión más violentas. 


\subsection{La Dictadura franquista}

El Régimen franquista impuso un modelo de sociedad jerárquica, machista, desigual e injusta, en la que los derechos y libertades quedaban comprometidos seriamente para la mayoría de la población. Ello venía a superponerse a la destrucción humana y material consecuencia de la guerra y una postguerra de desabastecimiento, brutal represión y castigo de los perdedores, con torturas, juicios sumarísimos a penas de muerte, campos de trabajos forzados y de exterminio, vejaciones públicas a las mujeres republicanas, con miles de muertes y desaparecidos que aún siguen en las cunetas. Y en lo que respecta a los derechos de las mujeres (Osborne, 2012) la dictadura recuperó el viejo modelo "ángel del hogar" con una construcción de lo masculino y lo femenino totalmente dicotómica, atribuyendo al hombre cualidades y atribuciones (valiente, con carácter, jefe y proveedor) contrapuestas a las de la mujer (humilde, piadosa, sacrificada y entregada a los demás), supuestamente complementarias, formando una perfecta y divina unidad apoyada por la iglesia católica. Un único modelo masculino/femenino, en la familia y la escuela, difundido en blanco y negro por el nodo en los cines, bajo censura, seriales y consultorios sentimentales de radio y televisión, periódicos y revistas sobre moda, belleza o consejos prácticos del hogar y cuidado de los hijos. Y en contraposición a este modelo se nos ofrecía el de las republicanas feministas, "marimachos" que habían perdido la feminidad en sus locas pretensiones de igualdad.

Bajo estas directrices y al amparo de un sistema legislativo reaccionario, se crían las niñas que años más tarde encabezarán el movimiento feminista español. El régimen franquista incapacitaba a la mujer subordinándola al padre o marido, acabando con los avances del periodo republicano: fin del matrimonio civil y al divorcio, restablecimiento del delito de adulterio y amancebamiento, vedo a ciertos puestos de trabajo, "dote" a quienes dejasen el empleo al casarse y retirada de plus familiar a las que no, además de exigirse permiso marital para contrato laboral. Hasta los años 50 no se inicia una serie de cambios políticos, socioeconómicos y jurídicos, reformándose artículos del Código Civil para aligerar un poco todo ello, cambios que en los 60 aceleraron el débil crecimiento industrial español (descenso de la mortalidad y control de la natalidad, mayor escolarización y mayores tasas femeninas en enseñanzas medias/universitarias). Hubo también cierto cambio generacional, cuestionándose el modelo de familia tradicional, autoritaria y controladora, a favor de otra más permisiva que otorgaba a sus miembros mayor independencia, con pugna también en el diferente papel que las mujeres jóvenes querían seguir respecto a sus madres o en torno al carácter exclusivo y excluyente del trabajo doméstico. A partir de los 60 empieza a derrumbase la estructura moral/sexual/católica, relajándose las relaciones entre los sexos, con más permisividad hacia prácticas como las relaciones prematrimoniales y una sexualidad más libre. Ya habían aparecido obras como La secreta guerra de los sexos de María Laffitte y El segundo Sexo de Simone de Beauvoir, aunque este último, al estar prohibido por la Iglesia Católica, no había sido publicado en España.

Durante la dictadura, las mujeres se incorporan de manera significativa en la lucha antifranquista, en organizaciones clandestinas (partidos políticos, sindicatos, comités de solidaridad, etc.) en las que se reclama reconocimiento, liderazgo e igualdad, allí donde había posibilidad de reunirse (barrios, universidades y empresas). Aunque lo que predominaba era la lucha democrática, junto a las reivindicaciones generales también se incluían algunas que les afectaban especialmente, como la petición de guarderías en los barrios, la no discriminación salarial en las empresas, poder elegir carrera en libertad, trato en igualdad en las aulas o llevar pantalones en la universidad. Y poco a poco, fueron creándose nuevas asociaciones de mujeres, como las siguientes (Gahete, 2018):

- 1953 Asociación Española de Mujeres Universitarias (AEMU). Continuidad de la de 1920.

- 1960 Seminario de Estudios Sociológicos de la Mujer (SESM). Intelectuales.

- 1964 Mujeres Libres, Continuidad de 1936/1939. Anarcosindicalistas. Feminismo/clase.

- 1965 Movimiento Democrático de Mujeres (MDM). PCE: AA. VV, Amas de Casa, sindicalistas. 
- 1971 Asociación Española de Mujeres Juristas (AEMJ). María Telo, Manuela Carmena...

- 1972 Asociación Castellana Amas de Casa y Consumidoras (ACACC). Vinculada a MDM/PCE

- 1973 Asociación para la Promoción y Evolución Cultural (APEC). Madrid.

- 1974 Asociación Española de Mujeres Separadas (AEMS) y Divorciadas. Asesoramiento.

- 1975 Asociación Nacional de Comunicación y Ecología (ANCHE). Ámbito catalán. Socialistas

- 1975 Seminario Colectivo Feminista. Madrid. Vinculado al feminismo radical.

- 1975 Asociación Universitaria Estudio Problemas de la Mujer (AUPEPM). Madrid. Socialistas.

- 1975 Colectivos Feministas del Estado Español (CF). El primero en Barcelona. Femi. Radical,

- 1976 Frente de Liberación de la Mujer (FLM). Feminismo Socialista.

- 1976 Lucha Antiautoritaria Mujeres Antipatriarcales y Revolucionarias (LAMAR). Radical/Dif.

- 1976 Asociación Democrática de la Mujer (ADM). PTE/ORT

- 1977 Organización Feminista Revolucionaria-Lidia Falcón-Anna Estany. Partido Feminista 79.

- 1977 Unión para la Liberación de la Mujer (ULM) ORT

\section{Corrientes de pensamiento: Feminismos plural. Organización.}

Si en los orígenes del feminismo a lo largo del siglo XIX y primeros años del XX las dos corrientes más importantes fueron sufragistas y socialistas, las primeras poniendo el acento en lograr el derecho al voto (desde la perspectiva liberal) gracias al cual suponían que podrían cambiar su situación, y las segundas poniendo el acento en la lucha de clases (desde la perspectiva socialista) que pudiera abrir el paso a su liberación, eso no quería decir que no hubiese más variedad de puntos de vista, ni que pese al enfrentamiento (unas tildadas de "burguesas", "puritanas" o "conservadoras" y otras de "antidemocráticas", "radicales" o "revolucionarias"), los logros de unas y otras no estén a la vista. Los logros sufragistas están claros. Socialistas, por su parte, eran A. Bebel y F. Engels, quienes escribieran "La Mujer" y "El origen de la familia, la propiedad privada y el Estado", respectivamente, dos obras ampliamente leídas y criticadas muchos años después. Socialistas eran Clara Zetkin, Rosa Luxemburgo (a quien Lenin reconoció haber volado como águila y no como tantos gallinas) y Alexandra Kollontai (la bolchevique enamorada), que fue quien dio un paso más allá de la lucha de clases, reconociendo que la llegada al socialismo no garantizaba la liberación de las mujeres, sino que habría que conseguir otros avances sociales para que surgiera un nuevo hombre y una mujer nueva, reivindicando cambios en las relaciones sexuales, la socialización del trabajo doméstico y hasta el amor libre. Sin olvidar a Flora Tristán, que tan clara tenía la importancia de nuestra educación. Poderosas mujeres, de lúcido pensamiento crítico, ampliamente criticadas en sus partidos y en la sociedad de su tiempo.

El feminismo que surge después de la segunda guerra mundial, con poca incidencia en España, tuvo también dos grandes corrientes, la marxista y la radical. Aunque en realidad ambas parten de una base marxista, el feminismo marxista (socialistas, comunistas y anarquistas) sigue poniendo en el centro las clases sociales, trabajadora y burguesa, el sistema capitalista/opresor y la plusvalía del trabajo, mientras que el feminismo radical lo que hace es aplicar el marxismo a la mujer como clase oprimida por el hombre, denominando al sistema patriarcal/capitalista, obteniéndose en él la plusvalía bien de la reproducción y/o del trabajo doméstico. Así que, mientras las primeras serán partidarias de la doble militancia (clasista y feminista), las segundas verán incompatible compartir organización con "el enemigo" y defienden una organización propia de mujeres. De hecho, si observamos la relación de organizaciones de mujeres del capítulo anterior, creadas al final de la dictadura o mayoritariamente durante la transición, veremos que básicamente estarían, por un lado, las marxistas/clase/doble militancia (M. Libres, MDM, ACACC, ADM, ULM, FLM, AUPEM, ANCHE, AEMJ) y por otro las radicales/partido feminista (Seminario CF, CFM, CFB, OFR, LAMAR). Y en las "I JJ de Liberación de la Mujer" del 75 celebradas en Madrid semiclandestinamente, organizadas por MDM (vinculado al PCE), FLM (socialistas) y Seminario CF (radicales), se trataron 
muchos temas (educación, trabajo, familia, sexualidad, divorcio, anticoncepción, aborto), aunque los debates de fondo fueron marxismo, capitalismo/patriarcado y doble militancia o no.

A partir de ahí, avanzando el proceso democrático y tras la celebración de las I Jornades Catalanes de la Dona en el 76, con asistencia de 4000 personas, hubo una explosión y proliferación de grupos, comisiones y Coordinadoras, en todo el estado. En esas primeras reuniones y Jornadas, debatíamos los planteamientos de feministas marxistas, como A. Walters sobre "Marxismo y feminismo"(1978), E. Reen "Sexo contra sexo, clase contra clase"(1976), J. Mitchel y "La condición de la mujer" (1977) o Z. Einsentein sobre "Patriarcado feminista, feminismo socialista" (1978), pero también los de las radicales S. Firestone y "La dialéctica del sexo"(1970), K. Barry "La esclavitud sexual de la mujer" (1988), la "Política sexual” (1970) de K. Millet, así como “El principal enemigo" (1982) de C. Delphy, considerando a la mujer clase social, no sobre una base biológica, sino dada su condición de trabajadora doméstica no remunerada, mientras que Lidia Falcón, en "La razón feminista" (1981), ponía el acento en la función reproductora de las mujeres. También LAMAR, con Gretel Ammam a la cabeza, habló de clase sexual frente a clase social, mientras que Paloma Uría en "El feminismo que no llegó al poder" (2009) señaló lo confuso del concepto de reproducción del sistema social en la teoría marxista y de reproducción biológica en la teoría feminista. Otras aportaciones vendrán de autoras como S. Federici (2011), para quien el trabajo doméstico y la familia son los pilares de la producción capitalista, o Mạ Ángeles Durán, que en su obra "El ama de casa. Crítica política de la economía doméstica" (1978), defiende que la mujer como ama de casa realiza un trabajo. Variedad de puntos de vista, por tanto, dentro de ambas corrientes y más allá de ellas. Así se describe esa vivencia en primera persona:

"Mis responsabilidades políticas y profesionales, viviendo ya de forma independiente con mi pareja, no me impidieron ni mucho menos participar y seguir bien de cerca el surgimiento del movimiento feminista en Catalunya, especialmente en Barcelona y particularmente en Sabadell, Santa Perpetua de la Moguda y otras localidades del Vallés. Recuerdo aquellas primeras reuniones, encuentros y debates en "LaSal", LLibrería de les Dones" y sus "Cuadernos Inacabados". Allí discutíamos sobre los orígenes de nuestra opresión, la contradicción fundamental, clase o sexo, el enemigo principal, marxismo y feminismo, la autonomía de las mujeres, la autoconciencia, lo privado/personal, lo público/político y el poder, la pequeña diferencia y sus grandes consecuencias, el sistema sexo-género, el patriarcado, la sexualidad femenina, lesbianismo, pornografía, prostitución, salud, la regla, los anticonceptivos, el aborto y la maternidad, nuevas tecnologías de reproducción y un largo y etc. Unos debates apoyados por textos de destacadas feministas francesas, italianas y americanas, como S. de Beauvoir, Cristine Delphi, Luce Irigaray, Carla Lonzi, Silvia Federici, Kate Millett, Betti Friedan y muchas más, que fueron perfilando las ideas y posicionamientos de las distintas corrientes feministas de nuestro movimiento, siempre muy plural, porque ya desde el principio, allí estaba Lidia Falcón forjando las bases de su Partido Feminista, poniendo el acento en el marxismo, el patriarcado, los hombres como adversarios, la independencia organizativa de las mujeres como clase social; Gretel Ammann de la corriente de feministas Independientes, poniendo el acento en la autoconciencia, la diferencia y autonomía de las mujeres de los hombres y de los partidos, contra la pornografía; Empar Pineda reivindicando el lesbianismo frente a la heterosexualidad obligada, impulsora de la Comisión Pro Derecho al Aborto y del Colectivo de Lesbianas; Cristina Garaizábal, por la libertad sexual, la anticoncepción, el placer y la diversidad sexual, la transexualidad, la prostitución y contra todas las Violencias Machistas, etc. Otros feminismos por la igualdad se expresaban también ya en el ámbito académico e institucional (PSOE) y partidista (PCE, PTE/ORT) o en los incipientes movimientos pacifistas y ecologistas, el ecofeminismo. (Almirón, 2020: 353/382).

Pronto aparece, además, como vemos, el debate del feminismo de la igualdad (marxistas) versus feminismo de la diferencia (radicales), que Gahete S. (2018) cree necesario abordar, ya que, aunque en España tuviese menor incidencia en sus primeros años, fue un debate importante en el resto de 
Europa y EEUU, desde entonces hasta hoy. Su núcleo fuerte estaba en Italia, con Carla Lonzi y su "Escupamos sobre Hegel" (1971), postulando una identidad propia, la mujer, como sujeto pensante y autónomo, no sólo sobre sí misma sino sobre la historia y la sociedad en general, reclamando lo femenino como lo diferente, no inferior. Y en ello estaban a finales de los 70, las mujeres del Centro Cultural Virginia Woolf de Roma(1971) y las mujeres del Colectivo Librería delle donne di Milano (1971).Sin embargo, las referentes, de la mano de Gretel Ammam, quien introduce aquí los grupos de autoconciencia del feminismo cultural, serían más bien las francesas, Annie Leclerc, Hélène Cixous y especialmente, Luce Irigaray "Speculum.Especulo de otra mujer" (1974), del grupo Psicoanálisis y Política, que criticó duramente el feminismo igualitario por reivindicar la equiparación de derechos entre hombres y mujeres, en lugar de ahondar y reivindicar la diferencia entre ambos.

El feminismo de la diferencia recibió distintas críticas al considerar que recuperar la <esencia femenina>, que tanto ha oprimido a las mujeres, era caer en la trampa del simbolismo patriarcal. El feminismo de la igualdad luchaba para que los principios proclamados como universales se extendiesen a las mujeres, como seres humanos dotados de razón, formando parte al igual que los hombres de la ciudadanía e intentando también hacer posible la integración de valores en igualdad, trastocando y rechazando los valores imperantes asignados a hombres y a mujeres (Blanco, 2012). Es importante señalar las reflexiones de Gisela Bock (2001) sobre los conceptos de igualdad y diferencia, tomando el ejemplo de las feministas negras en EEUU (Davis, 2004), quienes en 1968 ya señalaban que la cuestión de fondo no era solo si las mujeres quieren la igualdad, sino si todas/os quienes han estado subyugadas/os por el modelo patriarcal de hombre blanco, quieren la igualdad, estando dicha igualdad medida por los patrones del hombre blanco y presentándose la diferencia para las mujeres como algo homogéneo, cuando no todas las mujeres conforman su identidad femenina de la misma manera. La idea planteada por Gisela Bock es que era necesario que las mujeres reconocieran su pluralidad, respetando y reconociendo el derecho a ser diferentes (identidad) e iguales (en derechos), cambiando el significado de los conceptos de igualdad y diferencia. El feminismo de la diferencia versus igualdad, se verá superado por las concepciones de otros feminismos como el lesbianismo o el queer, que pusieron el acento en la sexualidad, concibiendo la heterosexualidad como una institución social obligada que afecta a las mujeres directamente al ser transmisoras y reproductoras del sexismo, reforzando el poder masculino y su dominación sobre a las mujeres.

Por supuesto que no todo fueron debates. En pocos años, el movimiento feminista conoció un fuerte crecimiento organizativo con un marcado perfil crítico y reivindicativo, al que se incorporaron con entusiasmo nuevas generaciones de feministas (Almirón, 2020):

"El debate en torno al feminismo alimentó su desarrollo y un crecimiento organizativo importante del movimiento feminista especialmente activo y reivindicativo, impulsando como decíamos las primeras campañas, contra el adulterio y a favor del divorcio, los centros de planificación familiar, la legalización de los anticonceptivos y del aborto libre y gratuito. Grupos de mujeres que fueron dando lugar a coordinadoras comarcales, provinciales y nacionales, como la Coordinadora Feminista de Catalunya, del País Vasco, Madrid, Andalucía...y la Coordinadora de Organizaciones Feministas del Estado Español (77), impulsándose Campañas, Comisiones y Jornadas, generales o temáticas en cada sitio y a nivel estatal. Se impulsaron igualmente Vocalías de Mujeres (barrios), Secretarías de la Mujer (Sindicatos) y Áreas de la Mujer en otras organizaciones, entidades y asociaciones mixtas. La fuerza de este movimiento feminista se ha hecho notar desde sus inicios en la lucha por sus reivindicaciones, algunas de ellas conseguidas más rápidamente, como la legalización de los anticonceptivos (78), Centros de Planificación Familiar (78/79), el divorcio (81) o el aborto (85), aunque hemos ido comprobando que los derechos no se consiguen para siempre sino que los intentos de revertirlos también se han ido dando y la Violencia Machista parece no tener fin, ni retroceso."(Almirón, 2020: 364). 
El sistema organizativo se decide que sea asambleario, sin jerarquías ni cargos directivos, proclamándonos autónomas e independientes de partidos e instituciones, con un enfoque unitario, pese a la diversidad de colectivos (multitemáticos, lesbianas o heteros, trabajadoras, estudiantes o académicas...) y la pluralidad de puntos de vista expresados en los debates y jornadas a las que asistíamos todas, no siempre fáciles de gestionar, a falta de experiencia y dada la jerarquización y homogeneidad ideológica existentes en la mayoría de organizaciones, a izquierda y derecha, de la época. Tan solo cuatro años después de aquella "I Jornada de Liberación de la Mujer" del 75 en Madrid, se celebraron las "II JJ Feministas Estatales" del 79 en Granada. Con una participación masiva, se llega con mucho trabajo hecho y muchos temas para debatir, en un momento en que cristalizaban las corrientes de pensamiento. El Partido Feminista, las radicales de Lidia Falcón, se habían constituido en mayo del 79 y el feminismo de la diferencia salió de aquellas Jornadas con una Coordinadora de Independientes en 1980. Para algunas aquello parecía el fin, y para otras era solo el principio de todo lo que después vendría.

\section{La creciente diversidad de perspectivas feministas.}

En las II JJ Feministas Estatales de Granada del 79 no solo se evidenció la pluralidad de ideas del movimiento feminista ya existente, más allá incluso del llamado feminismo radical, pro igualdad y cultural o de la diferencia. La misma participación, proliferación de grupos y amplitud de temas abordados evidenció también la diversidad de mujeres que allí acudíamos, desde diferentes ámbitos y situaciones de trabajo; orígenes, territorios del estado, ciudades o pueblos; edades, orientaciones sexuales y situaciones afectivas, etc. Todo lo cual rompía con la idea de "la mujer", como un todo homogéneo, a la que no afectaran esos otros factores a la hora de reconocer e interiorizar su subordinación. Una diversidad de perspectivas feministas que no ha dejado de crecer desde entonces.

Habiendo una inmensa mayoría de mujeres feministas de izquierdas implicadas en la lucha antifranquista (más que doble militancia era triple, o más), las demandas feministas no tardaron en llegar a las propias organizaciones y sindicatos, reclamando Áreas y Secretarías de la Mujer que ampliaran y apoyaran las reivindicaciones de las mujeres. Interesante fue la experiencia de CCOO, con Secretaría de la Mujer desde el 76, rompiendo con la vieja idea de que lo primero era sólo la lucha de clases, una durísima batalla ideológica que ganaron las sindicalistas y que llevaron por escrito a Granada en el 79. Desde las Secretarías se han apoyado luchas tan importantes como la incorporación al trabajo en las minas de las asturianas en el 84, otra tremenda batalla contra el machismo, disfrazado de paternalismo y proteccionismo, empresarial y sindical. Se ha luchado contra el acoso sexual y defendido los derechos de las trabajadoras en sectores muy feminizados, como sanidad o enseñanza, que tantos recortes han sufrido, o especialmente precarizadas, como las trabajadoras de las conserveras, especialmente del 85/87, tras la reconversión del sector, de ahí sus luchas:

"...apoyo a las mujeres de las conserveras, fundamentalmente de Ubago, en proceso de ser elegidas delegadas sindicales y representantes del Comité de Empresa, sindicar al resto de trabajadoras y dejar de ser representadas por los encargados varones, suponía un importante avance pero también un trabajo de empoderamiento y acompañamiento a estas mujeres, que superaba con creces el trabajo de lo que se entiende como meramente sindical...para huelga emocionante la de Ubago, con toda la plantilla de mujeres taponando la entrada, en corro, mientras tejían y cosían, como si nada, ellas nunca pierden el tiempo,... iUnas valientes!" (Almirón, 2020: 369).

Paloma Uría (2009) hace un buen recorrido sobre la importancia que el trabajo de las mujeres ha tenido en todas y cada una de las jornadas feministas celebradas, con aportaciones de académicas 
como Mo Ángeles Duran (1978) o Cristina Carrasco (2006), sindicalistas, o las propias trabajadoras, ya que al margen de los sindicatos tuvieron que empezar a organizarse en el 85 las empleadas domésticas de Bilbao, apoyadas por la Asamblea de Mujeres de Vizcaya, aumentando desde entonces hasta hoy las asociaciones de trabajadoras, limpiadoras, como las Kellys, cuidadoras migradas, con o sin papeles, o las trabajadoras sexuales.

En pueblos y barrios se impulsaron Grupos de Mujeres y Vocalías de Mujeres en las AA.VV, vinculadas al movimiento feminista, añadiendo a la lucha contra la carestía de la vida y la solicitud de servicios públicos, como Guarderías y Centros de Atención, que aliviaran la carga de los trabajos domésticos y cuidados, la puesta en marcha de Centros de Planificación Familiar, sumándose a la campaña del movimiento feminista "sexualidad no es maternidad", a favor de la legalización de los anticonceptivos y de la interrupción voluntaria del embarazo, abriendo por tanto el debate sobre las prácticas sexuales dominantes orientadas sólo a la reproducción, la libertad de ser o no madres, la reivindicación del placer para las mujeres y las diferentes orientaciones sexuales para las que debería haber también libertad. Después fue cogiendo fuerza, además de las actividades y movilizaciones entorno al 8 de marzo, la campaña contra la Violencia Machista, especialmente el 25 N. Debates y campañas que pese a haberse logrado, en el 78 la legalización de los anticonceptivos, los Centros de Planificación Sexual en el 79 y el aborto en el 85, han seguido teniendo lugar, dados los intentos de retrocesos en el caso del aborto y dado que la violencia machista parece no tener fin. Todo ello indica que el debate sobre la sexualidad, en general, no está ni mucho menos cerrado, con la existencia además de prostitución en la periferia urbana o la importancia de la pornografía en las redes, entre menores, etc.

No menos visible es el crecimiento de la diversidad sexual, que se expresaba en las Jornadas del 79 de Granada con una notable presencia de lesbianas, que ya habían participado en las manifestaciones del orgullo gay del 76 en Barcelona y del 77 en Madrid y que en el 81 crearon el Colectivo de Feministas Lesbianas de Madrid vinculado al movimiento feminista, editando el magnífico boletín "Nosotras, que nos queremos tanto", hasta celebrarse las Primeras JJ Estatales sobre Lesbianismo en el $87 . \mathrm{Y}$ en 1993, las transexuales hicieron su entrada triunfal en el movimiento, mostrando otras formas de ser mujer y otras violencias, profundizando la crítica a la heteropatriarcalidad obligada y al binarismo de sexo y género:

"Lo mejor del 93, las JJ Feministas Estatales "Juntas y a por todas" de Madrid... más de 3000 mujeres y en particular, aquella Mesa coordinada por Cristina Garaizabal en la que tres mujeres transexuales andaluzas, Kim, Merche y Paqui nos contaron su historia, sobre cómo ser mujer y no morir en el intento, entrando por la puerta grande en el movimiento feminista sin pasar por taquilla, mostrando que hay muchas formas de ser mujer y feminista, le pese a quien le pese". (Almirón, 2020: 370).

En la actualidad, muchas lesbianas siguen formando parte de las asambleas feministas y las relaciones con los colectivos de lesbianas y trans, más autónomos, siguen siendo estrechas, participando en las distintas actividades y movilizaciones feministas.

En el ámbito académico ha habido un gran desarrollo de los "estudios de la mujer", sobre sexualidad y género, desde casi todas las disciplinas (historia, antropología, derecho, sociología, trabajo social, ...). Fue en las JJ Feministas Estatales en Madrid del 93 donde la presencia de las académicas fue notable. La perspectiva feminista académica es también muy plural, con una gran variedad de puntos de vista sobre todos y cada uno de los temas abordados, como han puesto de manifiesto las jornadas de debate sobre trabajo sexual. Tanto es así que unas, declarándose abolicionistas, han instado a su prohibición, otras se han abierto al debate, y otras se han pronunciado a favor de los derechos de las prostitutas. El peso de las académicas es por tanto muy importante en el desarrollo del feminismo, aunque se trate de una influencia más desde fuera que desde dentro del 
movimiento, desarrollándose en ámbitos distintos, con dinámicas propias, motivaciones e intereses no siempre coincidentes, aunque solo sea por desconocimiento mutuo.

En la periferia del movimiento, al ser éste un movimiento de mujeres (aunque cada vez más diversas y pese a la crítica al binarismo del sexo y género) estaría el de los grupos de hombres por la igualdad, cuyas redes tienen ya una trayectoria de más de 40 años. J.V. Marqués escribió "La alienación del Varón" (1979) y empezaron a reunirse un grupo de hombres convocados por J. Á. Lozoya, tras el que vendrían muchos otros grupos repartidos por todo el estado. En 1999 en Jerez, J. A. Lozoya dirige el programa "Hombres por la Igualdad, en 2001 fueron las JJ. Estatales "Los hombres ante el reto de la igualdad" y se crea AHIGE y, a partir de ahí, otras tantas jornadas, encuentros y congresos, intensos debates y campañas reivindicativas, contra las agresiones machistas o a favor de los cuidados. De 2003 es "La construcción cultural de las masculinidades" de Valcuende y Blanco (eds.) y de 2012 "Hombres. La masculinidad como factor de riesgo. Una etnografía de la invisibilidad", tesis doctoral de Juan Blanco. Se trata de hombres que cuestionan el modelo opresivo de masculinidad dominante y participan en las movilizaciones y actividades feministas, apoyándolas y encargándose de las redes de cuidados que suelen organizarse, especialmente en las huelgas feministas, mostrando así su solidaridad, considerados aliados, pero no parte integrante del movimiento feminista.

Una de las principales críticas al feminismo a partir de los 80/90, reafirmada por el auge de los feminismos negros (Davis, 2004), decoloniales y periféricos (Bock, 2001), será precisamente a esa consideración de un sujeto unificado dentro del feminismo, encarnado en las mujeres. En palabras de Empar Pineda (2009):

"Hemos aprendido que la identidad de las mujeres es múltiple. No existe <la mujer>, sino mujeres con intereses diversos, incluso contradictorios. Antes teníamos una especie de feministómetro para decidir quién era realmente feminista. Ahora con algunas mujeres puedes caminar tres kilómetros, con otras veinte y con otras cien, pero debemos ir juntas. Ese es el reto." (Pineda, El País 13/12/2009).

Efectivamente, la importancia de los feminismos negros, decoloniales y periféricos, no ha dejado de crecer, en EEUU y Latinoamérica, con importantísimas movilizaciones, pero también en Europa y en casi todo el mundo, ampliando las perspectivas feministas de sexo, género, clase y raza, cuya presencia en el movimiento feminista de este país es también notable. Ya no somos aquel movimiento de blanquitas estudiantes universitarias, sindicalistas y trabajadoras sanitarias, maestras o profesoras, conserveras o mineras, jornaleras agrícolas, limpiadoras o trabajadoras domésticas marginadas de los sindicatos. Ya son cientos de mujeres marroquíes que recogen la fresa en las peores condiciones y sufren acoso sexual, y de muy diversas nacionalidades que trabajan en la industria agroalimentaria, migrantes con o sin papeles las que hacen de cuidadoras de hogar y limpiadoras. Y en los barrios populares ya no hay solo amas de casa, payas o gitanas, sino que no son pocas las nigerianas o guineanas, africanas y latinoamericanas, que llevan a sus hijos e hijas a las escuelas o necesitan guarderías para poder ir a ganarse la vida de muchas maneras, incluyendo el ejercicio de la prostitución. Mujeres que hace mucho que están pero que ahora, más afirmadas y empoderadas, se reclaman feministas. De ahí que haya una Comisión de Racializadas que lleva ya tiempo funcionando a nivel estatal y que sea uno de los ejes de cualquier movilización, huelga feminista u 8M. De ahí su presencia tan activa en las últimas JJ. Feministas tanto de Catalunya (2016) como de Euskadi (2019). El concepto de interseccionalidad cobra plena vigencia en el movimiento, poniendo en el centro más que nunca el debate sobre las identidades, tomando fuerza la racialidad que rompe la homogeneidad del sujeto "mujer", pero abriendo también el debate crítico a las místicas esencialistas de la feminidad en las distintas culturas, señalando la disformidad del sistema sexo/género y las distintas formas de ser feministas en los distintos contextos. 
Paralelamente al desarrollo de dicho movimiento fue dándose una institucionalización del feminismo, que arrancara en 1977 con la decisión del Gobierno de UCD de crear la Subdirección General de la Condición Femenina, posteriormente Subdirección General de la Mujer, dentro del Ministerio de Cultura, cuya consolidación podríamos situar en 1983 con la creación del Instituto de la Mujer (IM), de gran importancia para el devenir del feminismo en este país. Pese a la diversidad de administraciones autonómicas con gobiernos de distinto signo, aquí vamos a referirnos a la institucionalización de mayor impronta, la encabezada por el PSOE, liderada por la corriente del feminismo socialista desde el 82 en que accede al Gobierno. Esta institucionalización ha supuesto reconocimiento de la importancia de la lucha por la igualdad, apoyo a sus demandas con los llamados Planes de Igualdad de Oportunidades y soporte al asociacionismo feminista, liderada como decíamos, por una sola de las corrientes del movimiento, la socialista. Una corriente que trataron de articular en el 83 PSOE/PCE, sin éxito, optando por hacerlo alrededor de las estructuras institucionales del IM y otras administraciones, a nivel central, autonómico y municipal. Así, alrededor de las instituciones se han ido creando y entrelazando toda una red de grupos y asociaciones, más o menos afines a dicho feminismo, con más o menos facilidades de acceso a las ayudas y subvenciones. Este feminismo institucional se desarrolla en pueblos, barrios y ciudades, en el ámbito sindical, con UGT/CCOO como sindicatos más cercanos, en el ámbito académico entorno a los llamados "estudios de la mujer", de forma más tardía (época de Zerolo y Zapatero) entre asociaciones de gays y lesbianas y mucho más recientemente con algún que otro hombre académico e igualitario. Desde el IM y Centros de la Mujer (CM) se sostienen cientos de actividades de todo tipo a lo largo del territorio, concentrando su acción en torno al $8 \mathrm{M}$ y el $25 \mathrm{~N}$ contra la "Violencia Machista". Con la institucionalización, el feminismo pierde autonomía (defendida por el feminismo de los 70 hasta hoy), constriñendo contenidos e iniciativas que escapen a las líneas políticamente establecidas, perdiendo pluralidad (participando cada vez menos en los debates feministas señalados, con toda su diversidad de puntos de vista, entorno, por ejemplo, a la sexualidad). Una línea de acción, entendemos, excesivamente defensiva, conservadora y victimizadora, unilateralmente centrada en el peligro de la sexualidad y en políticas punitivistas supuestamente protectoras, poco abierta al disenso de ideas y poco inclusiva, desde la diversidad de perspectivas feministas que han ido surgiendo (Garaizábal, CTXT 6/3/2020).

El problema, como ha planteado J. Butler (1990), es que, si desaparece la diferenciación dual en función del dimorfismo sexual, lo masculino y lo femenino, el sujeto hombre y el sujeto mujer, el feminismo así concebido e institucionalizado, podría desaparecer. Ese parece que sería el vértigo de muchas feministas. No el de E. Pineda (2009), quien opina que lo que podría desaparecer sería el movimiento de "la mujer", pero no el feminista. Otra cosa es cómo articular todo ello, con la necesaria autonomía y, a la vez, con la necesaria confluencia. Sin embargo, la organización ha ido dando pasos, tanto en las movilizaciones como en las JJ posteriores a las Estatales del 2009 de Granada, las celebradas en Catalunya (2016) y en Euskadi (2019), con asistencia de unas 3000 personas, donde se han ido afianzando unos ejes de trabajo comunes: sexualidades, decolonialismo, cuerpos, violencias y cuidados, en torno a los cuales han girado los debates, renovándose la crítica feminista anticapitalista, ecológica, antirracista y patriarcal, por la libertad y la diversidad sexual, antiautoritaria y contra las violencias machistas. Ejes que articularon la Huelga Feminista del $8 \mathrm{M}$ del 2019 y la del 8M de 2020, creándose para su organización las correspondientes Comisiones de Trabajo. En Sevilla, por ejemplo, para el 8M de 2020 las Comisiones fueron Cuerpos, Trabajo, Racializadas, Cuidados y, transversamente, medio ambiente, producción y consumo. Así, el movimiento sigue siendo asambleario, articulándose en torno a unos grandes ejes y con unos instrumentos de trabajo, las Comisiones. 


\section{La sexualidad, entre el placer y el peligro. Libertad vs censura}

Educadas en la época franquista, bajo el modelo "ángel del hogar ", las jóvenes feministas de los 70 iniciamos nuestra andadura poniendo en común nuestras particulares disidencias con ese modelo, que tan especialmente habían padecido nuestras madres y que, a partir de los 60, muchas de nosotras habíamos empezado a cuestionar, con la minifalda o la desaliñada pinta hippy, el deseo de estudiar y trabajar para no ser amas de casa, o atreviéndonos a tener relaciones prematrimoniales que, sin acceso libre a anticonceptivos, nos llevaron a más de un doloroso aborto ilegal, iniciando así la ruta de la liberación femenina, entre el placer y el peligro. Un aborto que en aquella época era algo así:

"Franco, como nos temíamos, murió matando apenas dos meses después, el 20 de noviembre de 1975 y tuve que contentarme viéndolo todo desde un hospital a las afueras de Londres, al que tuve que ir para poder abortar. El aborto en España estaba prohibido y te podían caer hasta doce años de cárcel... Estaba desesperada y acudí a una mujer que hacia abortos clandestinos en su casa. Me tendió sobre una mesa y trató de insertarme un palito para mantener abierto el útero y provocar el aborto, pero no fue así. Fueron mis compañeros y particularmente mis compañeras del MCC las que me advirtieron del grave riesgo de infección que corría y me informaron de los vuelos para ir a abortar a Londres. Mi novio y yo conseguimos reunir el dinero para el viaje, estancia de tres días y coste de análisis, visita previa e intervención médica que debería pagar allí. En aquel avión, la mayoría estaba claro que íbamos todas a lo mismo. Nos veíamos luego en las consultas médicas y hasta en el metro, con la botellita improvisada de orina, en dirección al hospital. Me trataron amablemente pese a no entender lo que me decían y no me dolía casi nada, pero solas, en aquella sala fría y extraña de hospital, algunas de las más jóvenes lloraban desconsoladamente llamando a sus madres y las demás lo hacíamos en silencio. Cuando se me pasó el efecto de la anestesia, me lavé, me vestí y me bajaron a una sala en cuya televisión, sin entenderlo en inglés, comprendí que Franco había muerto mientras yo abortaba y que miles de personas lo estaban celebrando en las Ramblas con cava. Sonreí amargamente maldiciendo al dictador por morir justo ese día, prometiéndome celebrarlo y luchar con todas mis fuerzas por el derecho al aborto, a mi vuelta. Tan solo dos semanas más tarde, el 6, 7 y 8 de diciembre del 75, de forma semiclandestina, se celebraban en Madrid las "I Jornadas por la Liberación de la Mujer", con más de 500 asistentes de todo el Estado." (Almirón, 2020: 361/362).

Reivindicarnos seres sexuales con derecho al placer no fue tarea fácil desde los inicios, y no por eso dejamos de hacernos casi todas las preguntas: ¿existe una sexualidad femenina más sorora, sensual y difusa, más vinculada al amor (romántico) y la reproducción, contrapuesta a otra sexualidad masculina más genital, agresiva, explícita y directa, no relacionada directamente con el amor ni los hijos? ¿No era ésa precisamente la definición heteropatriarcal del modelo "ángel del hogar", añadiendo el que nosotras no podíamos tomar la iniciativa sino solo consentir? ¿Tiene género el deseo sexual? A estas alturas del artículo ya sabemos que las respuestas no fueron dicotómicas sino muy diversas y plurales, más bien un depende de quiénes, cómo, dónde y con quién, un por supuesto que deberíamos poder tomar la iniciativa en igualdad y que si la tomaba el otro habría que consensuarlo y no forzar nuestra voluntad, dentro o fuera del matrimonio.

Debatimos con pasión, en profundidad, en concreto sobre nuestras prácticas sexuales, sospechando que tantos años de modelo "ángel del hogar" habría inclinado la balanza hacia ese dicotómico reparto de papeles entre hombres y mujeres, que veíamos necesario cambiar experimentando otras formas de relacionarnos y disfrutar pudiendo ser más, cada cual como quisiera, en la cama. Reivindicamos más caricias, menos genitalidad vaginal y más clítoris, saliendo mal parada la penetración/eyaculación sin más, aunque lo fundamental era que el comportamiento no fuera violento, denigrante ni discriminatorio. Pero de ahí a que hubiese una sexualidad considerada feminista, había un buen trecho: ¿quién la establecería y desde qué Código Feminista se sancionaría a quienes escapasen a dichas prácticas? 
Hubo por tanto una crítica a la desexualización de las mujeres y a la ideología heteropatriarcal, reivindicando el derecho al placer, separándolo de la maternidad y del deber de consentir o ser forzada/violentada, dentro y fuera del matrimonio, eligiendo como lema "sexualidad no es maternidad" en la campaña de los anticonceptivos, "aborto libre y gratuito" para la del embarazo y "divorcio justo, sin víctimas ni culpables" para la del divorcio, lemas todos ellos en los que puede observarse el acento puesto en la libertad y los derechos, más que en las causas, el castigo y penalización de las mismas por el Estado. Se pide derecho al placer y a disponer libremente de nuestro cuerpo, y libertad de elección para separarse y poder ser o no ser madres, un debate especialmente controvertido en el movimiento feminista que, partiendo de su no obligatoriedad, las sensibilidades a favor y en contra resultaban particularmente extremas entre nosotras: desde otorgar a la maternidad el más absoluto valor simbólico, casi esencial, a contemplarla con la más absoluta negatividad como base de nuestra explotación, y entre medias muchísimas otras opiniones con pros y contras sobre los que elegir.

Nuestros debates sobre sexualidad se dan desde el principio, en todas y cada una de las jornadas organizadas a distintos niveles territoriales, como las JJ Estatales sobre Sexualidad del 83 en Madrid, al tiempo que se llevaban a cabo las campañas a favor de los anticonceptivos y el aborto, los primeros legalizados en el 78 y la despenalización del aborto en julio del 85:

“En julio del 85, el PSOE aprobó su ley de Despenalización Parcial del Aborto (sólo en tres supuestos, violación, malformación del feto o serio peligro de la vida de la madre), que fue contestada por el movimiento feminista en las Jornadas Estatales de Barcelona en noviembre del mismo año a la que asistimos más de 4000 mujeres y donde se hizo público que se habían practicado abortos fuera de esa Ley, ya que seguíamos reivindicando el aborto libre y gratuito, a cargo de la seguridad social."(Almirón, 2020: 369).

Avanzábamos por tanto en libertad y en derechos, pero seguíamos transitando entre el placer y el peligro, cuando en el 77 sufrimos la tremenda pérdida de Antonia España:

“.. el 15 de setiembre de 1977, nos despertamos con una noticia brutal, el asesinato de una joven de 16 años, de una familia de origen cordobés, la segunda de catorce hermanos, Antonia España Hernández, del barrio de Can Rull. La mataron a puñaladas cuando iba a trabajar, muy cerca ya de su centro de trabajo. La ciudad se conmovió y el Grup de Dones de Sabadell con ella. Era la primera vez que hacíamos un comunicado, una hoja contra la violencia a las mujeres, una tan triste pancarta. Acudimos a consolar a la familia que era de nuestro barrio y ella de nuestro grupo de jóvenes, presenciamos el dolor inmenso, las muestras de solidaridad, se constituyó una Comisión de Seguimiento en el Ayuntamiento y recabamos información policial. Deambulamos día y noche sin parar hasta el día siguiente a la hora del entierro. Fue una enorme manifestación, triste y fúnebre, a la que acudieron cientos de miles de personas, de punta a punta de la ciudad. Supimos que la había matado un pretendiente despechado y celoso. Vinieron compañeras de la Coordinadora Feminista de Barcelona y de los grupos de mujeres de las localidades iNinguna agresión sin respuesta! ¡Antonia, hermana, nosotras no olvidamos! pusimos en la pancarta, aunque la que salió en la foto del periódico fue la del grupo LAMAR con Gretel Ammam a la cabeza "No a la pornografía". Y no la olvido, porque Antonia España es para mí el símbolo de una larga lucha contra las agresiones, violaciones y asesinatos de miles de mujeres que siguen muriendo en el mundo todos los años.... Pero no lo conseguimos, aún no." (Almirón, 2020: 365).

Fue un asesinato horrible que conmocionó a toda la ciudad, se dice, y especialmente a las mujeres, claro. El riesgo de tener relaciones sexuales prematrimoniales de joven es que puedes quedarte embaraza ¿qué hacemos? ¿Aceptamos la prohibición y nos reprimimos o nos tomamos esa libertad exigiendo anticonceptivos y derecho al aborto? El grupo de jóvenes de nuestro barrio era un grupo de chicos y chicas, que salían de excursión, se reunían por las noches tras el trabajo, celebraban guateques y se enamoraban. Antonia eligió a otro chico de novio y rechazó tener relaciones con el 
que la mató, celoso y despechado, por aquel macabro y retrógrado machismo del "la maté porque era mía" y "si no es para mí, no es para nadie", que no había leído por cierto en ninguna revista pornográfica de las que había ya en todos los quioscos; pues por mucho que te excite una revista porno, lo terrible es tener una mentalidad tan machista que te lleve a matar si te rechazan. ¿Qué habría que haber hecho en este caso? ¿No tener grupo de amigos y amigas, no salir de casa por la noche, no trabajar en el textil, no haber elegido ella al novio, haber consentido...? En todo ello había cierto riesgo, pero Antonia quería trabajar, salir con su grupo de amigos y echarse un novio rechazando al más machista del grupo. ¿Cuántas campañas habrá que hacer desde la escuela, los medios, los grupos feministas, las instituciones, para cambiar esas mentalidades? Si salirse de la norma heteropatriarcal está prohibido y puede salirte tan caro, habrá que criticarla con todas nuestras fuerzas y movilizar todos nuestros recursos, para que el miedo no nos paralice, no nos bloquee, no nos eche para atrás ni inhiba la respuesta.

De todo ello seguimos hablando con detenimiento en las JJ Feministas Estatales "Contra la violencia machista" del 88 celebradas en Santiago y emprendimos otra de nuestras campañas estatales. En el 92 ocurrió la violación, tortura y asesinato de las tres chicas de Alcacer, que causó tan gran conmoción social en todo el país, al estar absolutamente mediatizada y tras Alcacer, vendrían años después las "Manadas" de Pamplona o Arandina. ¿Ayudan esas campañas mediáticas a paliar el miedo de las mujeres o más bien son las preferidas de la derecha más cavernícola que con el pretexto de protegernos nos quiere de vuelta a casa y asustadas, de "ángeles del hogar" de nuevo? Claro que tenemos que protegernos, pero sin renunciar a los espacios de libertad conseguidos. El mensaje feminista no puede consistir solo en alertar del peligro, sino que ha de seguir apostando por la libertad sexual de las mujeres, desarrollando nuestra capacidad de agencia y autonomía, como señala Cristina Garaizábal:

"La lucha contra las agresiones pasa por desarrollar nuestra capacidad de agencia en este terreno, por desarrollar nuestra autonomía, por tomar el espacio público y hacernos visibles como seres sexuales, por ir vestidas como nos apetezca y educar a las personas en que eso no implica que vayamos "buscando guerra", muchas veces nos gusta tan solo ser miradas porque cuando se quiere ligar, además de la manera como se va vestida se ponen en danza otras señales. Esta es la acción principal y no seguir tipificando como delito, calificándolas como agresiones, todas aquellas conductas que nos resultan molestas. Como quiere hacer la ministra de Igualdad, Irene Montero, proponiendo un nuevo delito cuando en los espacios públicos se realicen "proposiciones, comportamientos o presiones de carácter sexual que, sin llegar a constituir un trato degradante ni atentado contra la libertad sexual, crean para la víctima una situación intimidatoria" (El Periódico 23/01/2020). No podemos convertir en delito todo aquello que nos molesta, el camino es afirmarnos y enfrentarnos a ello." (Garaizábal, CTXT 6/3/2020).

Hemos visto cómo suele asociarse fácilmente pornografía con violencia machista. Tal vez tantos años de censura franquista e ideología heteropatriarcal apoyada por la Iglesia Católica, desde entonces hasta hoy, nos haya vuelto un tanto puritanamente desconfiados e incómodos ante la expresión visual explícita y directa de la sexualidad, la pornografía, otro de los debates más controvertidos dentro del movimiento feminista en torno al que no hay consenso. Claro que la pornografía reproduce, descarnada y mayoritariamente, las prácticas sexuales aún dominantes que desde el feminismo se han querido también transformar, pero lo que se propone no es tanto una mirada más abierta y diversa de la sexualidad, sino su censura y prohibición, llevándonos de nuevo al dilema placer y peligro, libertad versus censura. Desde el feminismo se critica también las consecuencias de la romanización del amor, más relacionado con el llamado "crimen pasional", el "la maté porque era mía" o "si no es para mí, para nadie" (caso Antonia España) y venimos prestando atención a la desmitificación del amor romántico. ¿Por qué entonces no se pide su censura ni mucho menos su prohibición y sí la de la pornografía? Ambos tienen que ver con las fantasías, unas sobre el amor y las otras sobre el deseo sexual, explicadas magníficamente por JL. 
Sampedro en "El amante lesbiano" (2014). ¿Qué hacemos con las fantasías? ¿Nos repudiamos por sentirlas y tratamos de reprimirlas? ¿Las reeducamos en otros valores, sentidos y significados? ¿O volvemos a los tiempos de la censura y la prohibición del Estado que con la excusa de protegernos nos dejó sin libertades ni derechos? Es más ¿y si las fantasías estuvieran mostrando o liberando una diversidad de prácticas sexuales que el modelo heteropatriarcal sigue negando? ¿Y si en la lucha por ser sujeto y no solo objeto no quisiéramos perder el derecho a jugar, a poder ser todos sujeto y objeto a la vez?

Para terminar, volvamos a la prostitución, el socialmente más estigmatizado de los trabajos, dentro también del propio movimiento feminista, desde los inicios, pero que ha cobrado últimamente gran virulencia, según señala Teresa Maldonado en "El debate intrafeminista sobre prostitución” (2019), hasta el punto de prohibirse que se pueda siquiera hablar de ella. Partíamos, nada más echar a andar, de que la sexualidad había que desvincularla del amor (romántico) y de la reproducción (maternidad). Partíamos del derecho al propio cuerpo a todos los efectos (parir, abortar, trabajar de modelo o de minera, hasta para morir). Partíamos de que lo fundamental era que el comportamiento no fuera discriminatorio, violento o denigrante para las mujeres, pero que de ahí a que hubiese una práctica sexual considerada feminista había un buen trecho, porque ¿quién la establecería y desde qué Código Feminista se sancionaría a quienes escaparan a esa práctica? Si esos siguen siendo nuestros planteamientos, ¿ por qué tendríamos que defender la abolición de la prostitución? ¿Porque desvinculada del amor, como ejercicio del derecho al propio cuerpo, algunas consideren que es denigrante? ¿Quiénes y desde qué catecismo feminista juzgan la prostitución? Y si no hay catecismo ni nadie con derecho a administrarlo, ¿el problema sería entonces que no se ve a las prostitutas con capacidad ni posibilidad de ejercer sus derechos de ciudadanía? Luego, las mujeres de los colectivos más discriminados, excluidos y estigmatizados, ¿no tienen derecho a decidir ni a elegir libremente? ¿Pueden elegir ser madres o abortar, divorciarse o no y hasta cuando morir, pero trabajar de putas no? Esto supera el dilema de la sexualidad, placer o peligro, versus libertad o censura, y plantea lisa y llanamente un serio problema de derechos o de privilegios, señalado por Beatriz Gimeno en "Prostitución. Cuestión de derechos y de privilegios" (2019).

\section{Reflexiones finales, retos actuales del movimiento feminista.}

El movimiento feminista de los años 70 en nuestro país, surge en un contexto de cambio político democrático y apertura sociocultural, en una sociedad particularmente machista y conservadora, que no había conocido movimiento feminista anterior similar al de otros países, como el sufragista en EEUU o Inglaterra, salvo la presión de algunas relevantes feministas en los años 20 y durante el primer gobierno de la II República. Un movimiento que definiríamos como progresista y transgresor, sumando la lucha feminista a la de los llamados nuevos movimientos sociales, con su crítica anticapitalista, ecológica, antirracista y antimilitarista, que se autoconstruyó asambleario, plural y heterogéneo, autónomo y unitario, especialmente en sus primeras décadas, en torno a los debates desarrollados en las múltiples JJ Feministas y las luchas emprendidas en común desde la Coordinadora Estatal de Organizaciones Feministas, contra el delito de adulterio a favor del divorcio, desvinculando sexualidad de maternidad, a favor de la libertad sexual, los anticonceptivos, el derecho al aborto, la diversidad sexual y contra las agresiones machistas. Un movimiento con un fuerte impulso hasta los años 90, aunque en el 2000 aún consiguiera reunir más de 3000 mujeres en las JJ Estatales "Feminismo es y será" de Córdoba y en el 2009 otras 4000 en las JJ Estatales "30 años de lucha feminista" en Granada, 2500 en las JJ Catalanes Radicalment Feministes (2016) y otras 3000 en las "V JJ Feministas de Euskal Herria" (2019), apreciándose la pluralidad de ideas y la diversidad de perspectivas feministas, tan lejanas ya de aquella "I Jornada de la Liberación de la Mujer" del 75 en Madrid y de aquellas "I JJ. Catalanes de la Dona" del 76 en Barcelona. 
El feminismo institucional se puede considerar la "joya de la corona" socialista, fuente de legitimidad política y piedra arrojadiza contra la derecha (ya sea cuando Gallardón intentó echar hacia atrás la Ley del Aborto o años más tarde contra el Gobierno del Partido Popular en coalición con Ciudadanos y el apoyo de Vox en Andalucía, conocido entre la izquierda andaluza como el "trifachito"). Una "joya" casi única, con la que tratan de hacerse con el "tesoro" social, hegemonizando el conjunto del movimiento feminista, ocasionando fuertes tensiones por ello, ya que no se pueden imponer puntos de vista institucionales partidistas, en un espacio colectivo que es plural y autónomo, donde las decisiones se toman por consenso, no dejándose fácilmente instrumentalizar (Alabao, CTXT 6/2/ 2019). Sin embargo, especialmente tras las multitudinarias movilizaciones del 8M del 2019 a nivel global, particularmente importantes en nuestro país, eso es lo que viene ocurriendo, tanto en los preparativos del $8 \mathrm{M}$ y $25 \mathrm{~N}$, como en los debates sobre trabajo sexual (prohibiéndose la jornada prevista en la Universidade da Coruña), libertad, diversidad sexual y transexualidad (cuestionándose los derechos de las personas trans en un documento interno del PSOE, retrasando la Ley sobre Transexualidad). Debates que han estado presentes desde hace muchos años en el movimiento feminista, con una variada gama de posiciones entre el abolicionismo y la defensa de los derechos de las trabajadoras sexuales, acrecentándose ciertamente la crítica a una concepción tan binaria del sistema sexo/género, pero que nunca había adoptado la virulencia actual (Maldonado, Pikara 11/12/2019). Las dos viejas corrientes, el feminismo radical liderado por Lidia Falcón (El Español 6/3/2020) y su Partido Feminista con "la mujer" como clase social sustentada en la reproducción sexual, y el feminismo socialista institucional, abolicionista, tránsfobo e impositivo (Cobo, El Plural 20/10/2019), vienen utilizando su influencia y su posición política y académica, tratando de imponer un legítimo punto de vista (Gimeno, CTXT 24/9/2019) como verdad moral feminista, amordazando el punto de vista de las demás y especialmente el de las trabajadoras sexuales y transexuales (Barrère, MT 2020).

Como hemos visto, confundir ese feminismo institucionalizado, encabezado por buena parte de la corriente socialista, unilateralmente abolicionista (Cobo, Tribuna Feminista-El Plural 14/09/2019) con el conjunto del movimiento feminista organizado, es una simplificación que no se sustenta ni con el análisis de los debates, ni con una mirada a la historia de un movimiento que tiene en el centro otros ejes de debate más amplios y plurales, en su crítica feminista al sistema capitalista/patriarcal, su binarismo sexo/género y consiguiente heteronormatividad, la racialización, el empobrecimiento de amplios sectores sociales y su peligrosa deriva ambiental, como hemos tratado de explicar. Ese feminismo institucional está siendo autoritariamente hegemonizante, tratando de homogeneizar en sus contenidos al conjunto del movimiento organizado, pero no es hegemónico. No lo es en Catalunya, ni en el País Vasco, ni en Galicia, ni siquiera en Andalucía, feudo socialista desde la transición, donde ni el 9 de febrero contra el recorte de subvenciones del "trifachito" a los grupos anteriormente financiados por el IAM, ni el pasado 8 de Marzo en Sevilla, fue capaz de aglutinar, defender y representar con su convocatoria institucional, los derechos y libertades del conjunto de las mujeres, siendo desbordadas por un arcoíris feminista congregado en torno a una Asamblea Feminista Unitaria Abierta. Esta pretensión de patrimonializar y hegemonizar el feminismo social que se consigue movilizar desde los diversos grupos y corrientes de pensamiento, reflejando una pluralidad y diversidad en ese sentirse feministas que va más allá del propio movimiento organizado, puede y debe considerarse como un error fundamental, tanto a nivel táctico como estratégico, a la hora de potenciar un movimiento social como el feminista, que como hemos venido señalando, es por definición tan amplio, diverso y plural. El verdadero reto que se plantea es tener la capacidad de aunar todo ello para no dar ni un solo paso atrás en los derechos y libertades logradas y vislumbrar desde todas las perspectivas feministas, qué nuevos pasos se pueden ir dando contra todas las formas de discriminación y subordinación. Y si se aceptase que el movimiento está en una cuarta ola feminista, con todos esos ejes de debate, que esta ola se defina 
sobre el eje de los cuidados mutuos (Rodríguez, 2010) y no sobre el abolicionismo impositivo desde el poder, que señale a modo de "línea roja", quién y qué es o no, verdaderamente feminista.

En el contexto actual de auge del conservadurismo a nivel global (Almirón, Mientras Tanto, Mayo 2020) y de ascenso, tanto ideológico como en representación institucional, de la ultra derecha en este país (Almirón, eldiario.es 21/01/2020), cuando uno de sus ejes centrales es precisamente el ataque a la llamada "ideología de género" concebida como pensamiento único, cuyo alcance no se debe menospreciar, pensamos que los feminismos no pueden situarse a la defensiva en el desarrollo de políticas públicas, retrocediendo en la defensa de los derechos de las personas transexuales (Infolibre 12/6/2020), sumándose en la práctica al espíritu más conservador de la época Trump (Infolibre 13/6/2020), ni dejando en el limbo los derechos y las ayudas a las trabajadoras sexuales en plena pandemia (Paula Sánchez CTXT 15/6/2020). Planteamientos que han supuesto la división política y la quiebra tan dolorosa en lo personal, del movimiento feminista, dejando en evidencia la incapacidad de forjar las tan necesarias alianzas para proteger a los sectores y colectivos de mujeres más necesitadas, excluidas, marginadas o estigmatizadas. Por todo ello y siguiendo a Nuria Alabao (2020), señalamos varios retos que el movimiento feminista, los feminismos, deben afrontar:

Autonomía institucional, iniciativa propia y capacidad de actuación, para poder ejercer una presión social que pueda ir más allá de los límites del tablero político correspondiente, colocando al feminismo a la ofensiva. Se necesita la fuerza del tsunami de todos los feminismos existentes y emergentes contra el viejo conservadurismo machista, a nivel global, que vuelve de nuevo en este país encabezado por la derecha más conservadora.

Radicalidad, apostando por seguir yendo a la raíz en la fundamentación de la crítica feminista a las estructuras, a la norma heteropatriarcal y el sistema binario sexo/género, volviendo a reconectar con el placer y no solo con el peligro de la sexualidad, protegiéndonos, pero afirmándonos, sin dar un paso atrás en los derechos (al propio cuerpo) y libertades (a elegir y decidir libremente). (Rodríguez, 2019).

Perspectiva social, interseccional e inclusiva, más allá de las exigencias del reparto de "cuotas" de poder, "techos de cristal" y "carreras", tratando de aunar y proteger especialmente a las más necesitadas, excluidas, marginadas y estigmatizadas, incluyendo todas las perspectivas feministas críticas, rompiendo con la idea de un sujeto feminista unificado "la mujer" (Iturrioz, 2020).

Apuesta decididamente democrática, de empoderamiento de la ciudadanía, con menor demanda de proteccionismo y tutela estatal, centrada en la garantía de derechos y libertades, más que continuar con las censuras y políticas meramente punitivistas (prohibiciones, penas y castigos), que termina generando víctimas (sin reparación) y culpables (sin reinserción) (Almirón, 2010).

Y por último, potenciar una unidad respetuosa con la heterogeneidad de perspectivas y la pluralidad, elemento históricamente distintivo del movimiento feminista, abriendo y no censurando, ni mucho menos prohibiendo, espacios de debate académicos y no académicos, más abiertos al debate y al disenso, siendo capaces de establecer alianzas entre los diferentes sectores del feminismo, lo que requeriría nuevas formas organizativas para articular, experimentando e innovando, algo que en la práctica es lo que han venido haciendo las feministas desde sus inicios. 


\section{Bibliografía}

Alabao, N./PÉREZ, M (2019) “¿Quién quiere romper el movimiento feminista?” CTXT 6/2/2019 https://ctxt.es/es/20190206/Firmas/24296/Nuria-Alabao-Maria-Perez-Colina-c.

Alabao, N. (2020) "Seis retos del feminismo (de base)" Mientras Tanto febrero 2020 http://www.mientrastanto.org/boletin-187/de-otras-fuentes/seis-retos-feminismo-d-base.

Almirón, A. (2020) "De mal a peor en igualdad, violencia de género y medidas antiabortistas". El diario.es 21/01/2020 https://www.eldiario.es/andalucia/APDHA.

Almirón, A. (2020) "Los poderes públicos sí pueden y deben prevenir la violencia de género. El Salto 12/02/2020 https://www.elsaltodiario.com/algarabias/poderes-publicos-pueden-deben-prevenirviolencia-.

Almirón, A. (2020) "La pandemia del coronavirus, una crisis del sistema con los cuidados en el centro". Mientras Tanto mayo 2020 http://www.mientrastanto.org/boletin-190/.

Almirón, A. (2020): Feminista de Izquierdas, en Nieto-Morales, C. Vázquez Fernánde, M. J. NietoCabrera, M. E. (Coord.) EI Trabajo de la mujer en el S. XXI. Dykinson.

Barrere, M (2020) “¿A que juega el feminismo?” Mientras Tanto Marzo 2020 http://www.mientrastanto.org/boletin-188/notas/a-que-juega-el-feminismo.

Barry, K (1988) Esclavitud Sexual de la Mujer, Barcelona. La Sal.

Bebel, A. (1975) La mujer, Barcelona. Fontamara.

Beauvoir, S. de (2011) El segundo sexo. Madrid, Cátedra.

Blanco López, J. (2012) Hombres. La masculinidad como factor de riesgo. Una etnografía de la invisibilidad. Tesis Doctoral - UPO.

Blanco, M. (2012) ¿Autobiografía o auto-etnografía? Desacatos (38), 169-178.

Bock, G. (2001) La mujer en la historia de Europa. Critica Barcelona 2001.

Briz, M., Garaizabal, C., y Juliano, D. (Coord.) (2007) La prostitución a debate. Por los derechos de las prostitutas. Madrid. Talasa.

Butler, J. (1990) El género en disputa. El feminismo y subversión de la identidad. Barcelona, Paidòs,

Carrasco, C. (2006) La Economía Feminista: Una apuesta por otra economía. En: VARA, M. J. (ed.), Estudios sobre género y economía, Akal, Madrid.

Cobo, R. (2019) "En la cuarta ola se ha impuesto definitivamente el abolicionismo" El Plural, Tribuna Feminista-14/09/2019 https://tribunafeminista.elplural.com /2019/09/.

Cobo, R. (2019) "Universidad sin prostitución" El Plural. Tribuna Feminista. 20/10/2019https://tribunafeminista.elplural.com/2019/10/universidad-sin-prostitucion/

Davis, A. (2004) Mujeres, Raza y Clase. Akal, Madrid.

Delphy, C. (1982) Por un feminismo materialista. El enemigo principal y otros textos. Barcelona, Cuadernos inacabados.

Durán, M. A. (1978) El ama de casa. Crítica política de la economía doméstica. Madrid, Zero.

Eisenstein, Z. (1978) Patriarcado capitalista y feminismo socialista. México, Siglo XXI.

Engels, F. (1970) El origen de la familia, la propiedad privada y el Estado. Madrid. Fundamentos. 
Falcón, L. (2020) Contra la manifestación del 8-M: "Está en manos de proxenetas y gays". El Español 6/3/2020. En https://www.elespanol.com/mujer/actualidad/20200306/feminista-lidia-falconmanifestaciohtml.

Falcón O’Neill, L. (1981) La razón feminista I. La mujer como clase social y económica. El modo de producción doméstico. Barcelona, Fontanella.

Federici, S. (2011) Revolución en punto cero. Trabajo doméstico, reproducción y luchas feministas. Madrid, Traficantes de Sueños,

Firestone, S. (1970) La dialéctica del sexo. Barcelona, Kairòs.

Fraser, N. (2013) Fortunas del feminismo. Madrid, Traficantes de Sueños.

Friedan, B. (1963) La mística de la feminidad. Madrid, Cátedra, 2009.

Gahete Muñoz, S. (2018) Por un feminismo radical y marxista en la Transición Española. El Colectivo Feminista de Madrid 1976/1980. Tesis doctoral - UCM.

Garaizabal, C. (2020) "La libertad sexual. Ese oscuro objeto de deseo". CTXT 6/3/20 https://ctxt.es/es/20200302/Politica/31266/sexo-deseo-feminismo-codigo-penal-cristinagaraizabal.htm.

Giddens, A. (1997) Modernidad e identidad del yo. El yo y la sociedad en la época contemporánea. Barcelona, Ediciones Península.

Gimeno, B. (2019) "Prostitución. Cuestión de derechos y de privilegios". CTXT 24/9/19 https://ctxt.es/es/20190918/Firmas/28489/prostitucion-institucion-patriarcal-desiguald.

Gimeno, B. (2007) Historia y análisis político del lesbianismo. La liberación de una generación. Barcelona, Gedisa.

Iragaray, L. (1974) Speculum. Especulo de otra mujer, Madrid. Saltés.

Iturrioz, J. (2020) “Feminidad hegemónica y perversidad" El Salto. 6/5/2020 https://www.elsaltodiario.com/feminismos/ feminidad-hegemónica-perversidad.

Jabardo, M. (ed.) (2012) Feminismos Negros. Una Antología. Madrid. Traficantes de Sueños.

Juliano, D. (2000) La prostitución, el espejo oscuro. Barcelona. Icaria.

Kollontai, A. (1976) Marxismo y revolución sexual. Madrid. Castellote.

Kokllontai, A. (1976) La mujer nueva y la moral sexual. Madrid, Ayuso.

Librería de Mujeres de Milán (1991) No creas tener derechos. La generación de la libertad femenina en las ideas y vivencias de un grupo de mujeres. Madrid, Horas y Horas.

Lonzi, C. (1971) Escupamos sobre Hegel. Buenos Aires. La Pléyade.

Maldonado, T. (2019) "El debate intrafeminista sobre prostitución". Pikara 11/12/2019 https://www.pikaramagazine.com/2019/12/el-debate-intrafeminista-sobre-prostitucion/.

Marques, J.V. (1979) La alienación del varón. El viejo topo, pp: 80/89.

Millet, K. (1970) Política sexual. Madrid, Cátedra, 2010.

Mitchell, J. (1976) Psicoanálisis y feminismo. Barcelona. Anagrama.

Mitchell, J. (1977) La condición de la mujer. Barcelona, Anagrama.

Montero, J. (1977) Movimiento feminista: una trayectoria singular. En Egido, Á. y Fernández Moreno, A. Mujeres en lucha. El movimiento feminista España. Barcelona, Anagrama. 
Nieto, J. A. (edit.) (1998) Transexualidad, transgenerismo y cultura. Antropología, identidad y género, Madrid. Talasa.

Olivan, M. (1984) Cuestionar la heterosexualidad como norma: un asunto político. Nosotras que nos queremos tanto. №1. pág. 7-12.

Osborne, R. (1991) Las prostitutas, una voz propia. Barcelona. Icaria.

Osborne, R. (2014) Mujeres bajo sospecha. Memoria y sexualidad 1930/1980. Madrid, Fundamentos.

Pheterson, G. (Compiladora) (1989) Nosotras las putas. Madrid. Talasa.

Pheterson, G. (2000) El prisma de la prostitución. Madrid. Talasa.

Pineda. E. (2009) "30 años después... ¿aún es necesario el feminismo? El País 13/12/2009 https://elpais.com/diario/2009/12/13/sociedad/1260658806_850215.html.

Pineda, E. (2011) Las otras feministas: cuestiones pendientes en la España actual. En Egido, Á. Fernández Asperilla, A. (eds.) Ciudadanas, militantes y feministas. Mujer y compromiso político en el siglo XX. Madrid, Eneida, pp. 249-260.

Pineda, E. (1982): El discurso de la diferencia. El discurso de la igualdad. En Actas de las Primeras Jornadas de Investigación Interdisciplinaria. Nuevas Perspectivas sobre la Mujer. 2 vols., Madrid, U. Autónoma, vol. I, pp. 257-271.

Rich, A. (1978) Nacida de mujer. Barcelona. Noguer.

Rodríguez Ruiz, B. (2010) Hacia un Estado post-patriarcal. Feminismo y ciudadanía. Revista de Estudios Políticos núm. 149, pp. 87-122.

Rodríguez Ruiz, B. (2019) El discurso del cuidado. Propuestas (de) constructivas para un Estado paritario, Valencia: Tirant lo Blanch.

Rowbothan, S. (1977) Mundo de hombre, conciencia de mujer. Madrid. Debate.

Rubin, G. (1989) Reflexionando sobre el sexo: notas para una teoría radical de la sexualidad. En Carol S. Vance (compiladora) Placer y peligro. Madrid, Revolución.

Sampedro, J. L. (2014) El amante lesbiano Madrid, Debolsillo

Scanlon, G. (1986) La polémica feminista en España 1868-1974. Madrid, AKAL.

Uria, P.; Pineda, E.; Oliván, M. (1985) Polémicas feministas. Madrid, Revolución.

Uría, P. (2009) El feminismo que no llegó al poder. Trayectoria de un feminismo crítico. Madrid, Talasa.

Valcuende, J.M. y Blanco-López, J. (eds.) (2003) La construcción cultural de las masculinidades. Madrid, Talasa.

Waters, M. A. (1977) Marxismo y Feminismo. Barcelona. Fontamara. 